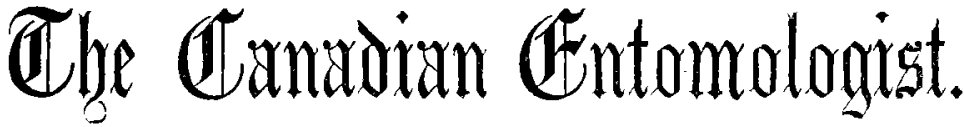

VOL. XVI. LONDON, ONT., SEPTEMBER, I884. No. 9

\section{SCOLYTUS RUGULOSUS IN BRANCHES OF PEAR TREES WHICH WERE KILLED BY PEAR-BLIGHT.}

BY DR. H. A. HAGEN, CAMBRIDGE, MASS.

During the years $1882-4$, large branches of young pear trees in Cambridge, Mass., were killed by pear-blight. The next year other branches were affected and killed, and finally the whole tree succumbed. All trees had been in good and healthy condition. The branches were more or less densely covered by a Coccid, determined by Prof. J. H. Comstock as Chionaspis furfurus (A. Fitch), described and figured in his Report for I 880 , p. 315, pl. I7, f. I. The Professor thinks it much more probable that the branches were killed by the Scolytid (directly to be mentioned) than by the Coccids, and I believe this opinion is justified by the fact that other pear trees and apple trees near by are also covered by the same Coccid and are nevertheless in a healthy condition.

The branches were densely inhabited by a Scolytus, which Dr. G. H. Horn determined as Scolytus rugulosus Ratzeburg. I was able to compare the beetle with specimens from Germany, which proved to be identical. The species was first mentioned by Dr. J. L. LeConte as introduced from Europe into the U. S., Proc. Amer. Philos. Soc., vol. xvii., p. 626, No. 79. The specimens were received from Elmira, N. Y., attacking peach trees. His collection contains, besides those from Elmira, N. Y., several specimens from Hillsboro, Md. Prof. Chas. V Riley informs me that he has ready for publication an extended article, with illustrations, upon $S$. rugulosus, and drew my attention to his note in the N. Amer. Entom., I880, vol. iii., p. 298 . The beetles were sent by Mr. J. L. Bennet, Red Bank, N. J. They had for several years destroyed all cherry, peach and plum trees set out on a particular lot at Fair Haven. They did not appear to injure seed fruit as yet, and are confined to a small section. They bore little holes in the trees, which holes fill with gum, and the tree soon dies. Mr. H. Boyè, Coopersburg, $\mathrm{Pa}$., communicated that the same beetle had so profusely stung a young cherry tree, trunk and branches, that it will not recover. Prof. Riley has received it from Hills- 
boro, Md., and from Williamsport, $\mathrm{Md}$., where it attacked the peach, and from the District of Columbia. As far as known to me, the N. American literature contains nothing more concerning this beetle.

In Europe the beetle is first quoted by F. Sturm (Catalog. meiner Insecten Sammlung, 1826, p. 194), with the manuscript name, Scolytus haemorrhous Megerle. In V. Kollar (Naturgeschichte der schaedl. Insecten, 1837 , p. 270 , and English transl. p. 263) the co-editor, J. Schmidberger, gives about the best account in existence of the beetle and its habits, with the same name, S. haemorrhous. Professor Ratzeburg, 1837, Forstinsecten, vol. i., p. I 87 , and Ed. ii., I839, p. 230 , gives in a note a description with the name Eccoptogaster rugulosus Koch, and quotes as synonym, Scolytus haemorrhous Ulrich. A good figure of the beetle is given pl. x., f. ro, and of the craddle and galleries in the bark, pl. I $7, f$. 4. The name Ulrich is explained by Schmidberger's statement that the beetle had been determined for him by Mr. Uirich as S. haemorrhous Megerle, and the article begins with this full name of the beetle. 'The name Koch, used by Ratzeburg, is a manuscript name. Mr. Koch, probably a student of the Professor, has nothing published. Nevertheless the beetle has been often quoted as $S$. rugulosus Koch, and only in later years as S. rugulosus Ratzeb. I do not understand why Ratzeburg has not adopted Schmidberger's name. That he has known this publication (though of the same year) is proved by the quotation of Ulrich's name. I am not able to see Schmidberger's work (Beitraege zur Obstbaumzucht und zur Naturgeschichte der-schaedlichen Insecten, I827 to i 836 ), which probably contains the same statements as in 1837 . The description by Ratzeburg without the figures would not allow a surer determination than those of Schmidberger, who gives besides a full history of the life and habits of the beetle. During the following time the literature on S. rugulosus is large. I have compared Noerdlinger, Letzner, Chapnis, Eichoff, Chapmann, Schmidt-goebel, for the observations on its habits. It attacks the branches, and often mere twigs, of living trees belonging to the genera Pyrus and Prunus, in great numbers, so that the infested part of the tree must perish, because it cannot continue to grow with injured bark and strongly pierced sap-wood. It appears to multiply very fast, and a double brood is supposed to occur. A few females laid so many eggs that the larvæ produced from them destroyed the bark of the stem, nearly a foot long. They cannot easily be eradicated, or at least diminished in numbers, but by removing and burning the trees attacked by them. 
As I believe it to be unfair to anticipate knowingly a communication which is near its publication, I would only give a short notice of some facts which may perhaps serve Prof. Riley in bringing to the front, at least for the cases observed by me, the connection of pear-blight with this beetle. The twigs were attacked about two feet above their origin out of the trunk, where they are about two inches thick, and higher up to half an inch thickness. The next year, if the dead branch is not removed, the beetle goes further down. The craddle is perpendicular in most cases, except where it begins just below the base of a bud, and is about an inch long. The galleries are to four inches long, and rather deeply injuring the sap-wood. The hole for the pupa goes deeply, to 4 millim., in the wood. I have observed the beetle only in pear trees, but I possess it from Europe on Prunus domestica.

I know Mr. F. J. Burrill's papers in Proc. A. Ass. 1880, p. 583, and Amer. Nat. $188 \mathrm{I}$, vol. $\mathrm{xv}$, p. $5^{27}$. I failed in trying to repeat his observations, what I consider of no importance against Mr. Burrill's conclusions, as just such observations need a trained skill not at my command. But I know that other scientists perfectly trained for such observations have also failed. As bacteria are everywhere to be found, we will have to wait for other reaffirming observations before we are able to accept $\mathrm{Mr}$. Burrill's views. I should add that I am acquainted with the older literature on pear-blight, and with the different hypotheses about its causes.

\section{HISTORY OF THE PREPARATORY STAGES OF PHYCIODES PICTA, EDw.}

BY W. H. EDWARDS, COALBURGH, W. VA.

EGG.--Sub-conic, truncated, the top convex, the upper part from one fourth to one third the length marked by low vertical ribs, about 24 in number; below these the surface is shallowly and irregularly indented; top similarly indented, convex; color when laid yellow green. Duration of this stage about five days.

YOUNG LARVA.-Length .04 inch at 12 hours from egg, cylindrical, each segment a little rounded; color yellow-green; a few long black hairs spring from minute black tubercles; these are in longitudinal rows, two being dorsal, and two sub-dorsal (one on either side); these rows run 